\title{
Communication
}

[Comunicação]

\section{Cheese yield, casein fractions and major components of milk of Saanen and Anglo-Nubian dairy goats}

\author{
[Rendimento de produção de queijos, frações de caseína e principais componentes do leite \\ de cabras Saanen e Anglo-Nubiana] \\ J.P. Damián ${ }^{1,2}$, I. Sacchi ${ }^{1}$, S. Reginensi ${ }^{2}$, D. De Lima ${ }^{1}$, J. Bermúdez ${ }^{2}$ \\ ${ }^{1}$ Facultad de Veterinaria - UDELAR \\ Lasplaces, 1550 - CP 11600 \\ Montevideo - Uruguay \\ ${ }^{2}$ Facultad de Agronomía - UDELAR - Montevideo - Uruguay
}

Over the last two decades, goat production had significant increments around the world, particularly in developing countries (Boyazoglu and Morand-Fehr, 2001). Most of the goat milk production is used for small-scale artisan cheesemaking. Cheese properties, quality, and yield depend on milk composition, especially protein, casein, and fat content (Storry et al., 1983; Ambrosoli et al., 1988). Milk composition is also influenced by breed, age, stage of lactation, lactation number, month of sampling, nutrition, and environmental and genetic factors (Storry et al., 1983). Breed has been frequently reported in the literature as one of the main variables affecting goat milk composition (Sung et al., 1999; Clark and Sherbon, 2000), including casein fractions (Clark and Sherbon, 2000; Moatsou et al., 2004). The proportion of the different casein fractions, particularly the $\alpha$ s1$\mathrm{CN}$ content, have been shown to influence coagulation properties, cheese yield, and protein content (Ambrosoli et al., 1988; Grosclaude et al., 1994; Clark and Sherbon, 2000).

Although there are studies that report the effects of breed on goat milk composition, researches in Latin America goat population are scarce and reports of breed effect (Saanen vs Anglo-Nubian) on casein fractions, milk composition, and cheese yield from goat milk under a semiintensive production system were not found. Saanen and Anglo Nubian breeds are among the most common goats raised in Uruguay. Two reports compared milk composition of Saanen and Anglo-Nubian breeds (Clark and Sherbon, 2000; Sung et al., 1999) and only the former studied the $\alpha$ s1-CN fraction in the same breed. Clark and Sherbon (2000) did not found a breed effect (Saanen vs. Anglo-Nubian) on as1-CN and total casein content, neither in coagulation properties. That study did not determine cheese yield or casein fractions. Thus, the aim of this study was to evaluate the individual milk components (fat, total protein, casein, and lactose $)$, casein fractions $\left(\alpha_{\mathrm{s} 1}-\mathrm{CN}, \alpha_{\mathrm{s} 2}-\mathrm{CN}, \beta-\mathrm{CN}\right.$, and $\kappa-\mathrm{CN}$ ) of two pure goat milk breeds, frequently raised in commercial Uruguayan dairy farms, and estimate the relationship between goat milk composition and individual laboratory cheese yield (ILCY).

Second lactation pure Saanen $(\mathrm{n}=11)$ and AngloNubian $(n=11)$ healthy goats, and raised under the same semi-intensive system and conditions, were selected from a commercial dairy farm in Canelones, Uruguay. All animals were fed pastures composed of lotus, clover, and rye grass. They also received a concetrate with $16 \%$ crude protein during milking time. Individual milk samples $(100 \mathrm{ml})$ from cows at mid-lactation (November) $(120 \pm 10 \mathrm{~d})$ were collected on two consecutive days (morning and evening milkings) before milking. Samples collected from each goat were carefully stirred and pooled 
as a proportion of milk production in each milking. Half of the samples was preserved in $0.05 \%$ potassium dichromate and kept at $4^{\circ} \mathrm{C}$ for casein fractions and chemical composition analysis. The other half (aseptically collected) was used for chesse making and bacteriological analysis (Moroni et al., 2005). For the later, milk samples were plated on blood agar and incubated for $24-48 \mathrm{~h}$ at $37^{\circ} \mathrm{C}$. Pathogens microrganisms were not found. No clinical signs of intramammary infections were observed for any of the goats throughout the study, hence, no mastitis therapy was administered.

Total nitrogen (TN) and $\mathrm{pH} 4.6$ soluble nitrogen (SN) were analyzed by the Kjeldahl method (Nx6.38). Casein nitrogen $(\mathrm{CN})$ was calculated as: $\mathrm{CN}=\mathrm{TN}-\mathrm{SN}$ (Official..., 1991). Fat and lactose contents were obtained by using a Milkoscan $^{\circledR}$ apparatus, according to the IDF (Whole milk..., 1996). Whole milk from each animal was skimmed by centrifugation at $2500 \mathrm{xg}$ for $30 \mathrm{~min}$ at $4^{\circ} \mathrm{C}$. Casein was obtained by isoelectric precipitation (3.3 $\mathrm{M} \mathrm{Na}$-acetate buffer, $\mathrm{pH}$ 4.6) from skimmed milk. The precipitate was centrifuged at $500 \mathrm{xg}$ for $20 \mathrm{~min}$ and further resuspended in distilled water for washing. The casein was precipitated once again by centrifugation, and washed with water three times. Casein samples of individual goat milk were obtained by dissolving one part (weight) of the casein precipitate with four parts (volume) of buffer (17.5mM 1,3-bis(tris)(hydroxymethylmethylamino-propano) at $\mathrm{pH} 7.4$ with $7 \mathrm{M}$ urea and $0.3 \%$ 2-mercaptoethanol. After standing at room temperature for $1 \mathrm{~h}$, each sample was filtered through a $0.2 \mu \mathrm{m}$ pore size filter (cellulose acetate ${ }^{1}$ ) and $40 \mu \lambda$ were injected for analysis by reverse phase high performance liquid chromatography (RP-HPLC), as described by Trujillo et al. (2000), which allowed to separate and quantify the relative amounts of the four major casein fractions $\left(\alpha_{\mathrm{s} 1}-\mathrm{CN}, \alpha_{\mathrm{s} 2}-\mathrm{CN}, \beta\right.$ $\mathrm{CN}$, and $\kappa-\mathrm{CN})$.

Casein standards ${ }^{2}$ were used for identifying casein fractions by RP-HPLC. Goat casein, 90\% purity (aprox.), determined by the method of biuret, and purified $\alpha-, \beta$, and $\kappa-\mathrm{CN}$ fractions ${ }^{2}$ were used. The fractions $\alpha_{\mathrm{s} 1}-\mathrm{CN}$ and $\alpha_{\mathrm{s} 2}-\mathrm{CN}$

${ }^{1}$ Sartorius AG - Germany.

${ }^{2}$ Sigma Chemical Co. - St. Louis, USA. were previously purificated as described by Igarashi (1999). Casein chromatography was performed on an Apex WP ODS reverse-phase column $^{3}(7 \mu \mathrm{m}, 4.6 \times 250 \mathrm{~mm})$ at $46^{\circ} \mathrm{C}$. Two solvents were used for the mobile phase as follows: A - acetonitrile-water-trifluoroacetic acid (100-900-1 v/v/v) and B - the same mixture with the proportions 900-100-0.7 (v/v/v). Proteins were eluted with a series of linear gradients: from 28.7 to $42.5 \%$ of solvent B in solvent A for $15 \mathrm{~min}, 42.5$ to $48.8 \%$ solvent B for $15 \mathrm{~min}$, 48.8 to $28.7 \%$ solvent $\mathrm{B}$ for $15 \mathrm{~min}$, finishing with $28.7 \%$ of solvent B for $15 \mathrm{~min}$ in order to column reequilibration. Flow rate was $1 \mathrm{ml} / \mathrm{min}$ and the eluted peaks were detected by UV-absorbance at $214 \mathrm{~nm}$. Quantification of the casein fractions was made by measurement of the peak area for each fraction as a proportion of the whole casein peak area. The concentration of casein fractions was expressed in $\mathrm{g} / \mathrm{l}$ or its relative percentage of total casein $(\%)$.

The ILCY was determined in duplicate for each individual milk sample as described by Othmane et al. (2002). The pooled samples were previously equilibrated at room temperature for $30 \mathrm{~min}$ before rennet addition. Ten $\mathrm{ml}$ of each preheated and homogenized sample plus $2 \mu \mathrm{l}$ of liquid bovine rennet ${ }^{4}$ were curdled for $1 \mathrm{~h}$ at $37^{\circ} \mathrm{C}$. The rennet was diluted at 1:20 with double distilled water before addition to the milk samples. The coagulum was cut (in way of cross with a spatula) and centrifuged for $25 \mathrm{~min}$ at $2500 \mathrm{rpm}$. The whey was decanted by inclining the test tube and the residue was weighed. ILCY was defined as the weight of the centrifuge residue expressed in kg/100 liters of milk. Milk composition, casein fractions, and ILCY were analyzed in a completely randomized design using the General Linear Model (GLM) procedure of the statistical software SAS (User's..., 2000). The statistical model included the effect of breed. Pearson's correlation coefficients were determined using the Corr Procedure.

Major milk components and casein fractions of Anglo-Nubian and Saanen dairy goats are shown in Table 1. Contents of fat, total protein and casein were significantly higher in Anglo-Nubian than Saanen milk $(\mathrm{P}<0.01)$. No difference was

${ }^{3}$ Jones Chromatography Ltd. - Mid-Glamorgan, UK.

${ }^{4}$ Pronacu Ltda - Montevideo, Uruguay. 
found for lactose content among the breeds. The contents of fat and protein confirm previous reports on these breeds studied under other systems of production, however, contents of lactose and total casein were different (Sung et al., 1999; Clark and Sherbon, 2000). Sung et al. (1999) worked with second or third lactation Anglo-Nubian $(n=9)$ and Saanen $(n=12)$ goats, reared under intensive husbandry conditions, and found greater levels of protein and fat and lower lactose content in Anglo-Nubian goat milk. Clark and Sherbon (2000) did not find differences in total casein content between breeds (Saanen vs. Anglo-Nubian), but found differences in protein and fat contents. In addition, coagulation properties: coagulation time, coagulation rate, and curd firmness were not significantly different between the breeds. On the other hand, cheese yield was not affected. However, the comparison between the present results and those reported by Clark and Sherbon (2000) is difficult because those authors did not inform the type of management or the lactation number. The present study was performed using a small number of animals (Nubian $\mathrm{n}=11$ and Saanen $\mathrm{n}=11$ ), but all of them were in the second lactation, kept under the same condition, and on the same farm.

Table 1. Major milk components (\%) and casein fractions (percentages in referring to total casein) of Saanen and Anglo-Nubian dairy goat (mean \pm SEM)

\begin{tabular}{lcc}
\hline Parametres & Saanen & Anglo-Nubian \\
\hline Fat & $3,59 \pm 0,24 \mathrm{a}$ & $4,65 \pm 0,17 \mathrm{~b}$ \\
Lactose & $4,54 \pm 0,05 \mathrm{a}$ & $4,53 \pm 0,03 \mathrm{a}$ \\
Total protein & $2,84 \pm 0,05 \mathrm{a}$ & $3,48 \pm 0,07 \mathrm{~b}$ \\
Total casein & $2,23 \pm 0,04 \mathrm{a}$ & $2,82 \pm 0,05 \mathrm{~b}$ \\
$\alpha$ s1-CN & $10,7 \pm 1,48 \mathrm{a}$ & $25,0 \pm 1,52 \mathrm{~b}$ \\
$\alpha$ s2-CN & $16,1 \pm 1,05 \mathrm{a}$ & $10,6 \pm 0,95 \mathrm{~b}$ \\
$\beta-\mathrm{CN}$ & $56,9 \pm 0,97 \mathrm{a}$ & $49,3 \pm 1,20 \mathrm{~b}$ \\
$\kappa-\mathrm{CN}$ & $16,3 \pm 0,57 \mathrm{a}$ & $15,0 \pm 0,76 \mathrm{a}$ \\
\hline
\end{tabular}

Means within a row without a commum letter differ $(\mathrm{P}<0.05)$

Figure 1 shows chromatographic pattern of $\alpha$ s1$\mathrm{CN}$ and whole casein of Saanen and AngloNubian milk by RP-HPLC. Table 2 shows the coefficients of correlation between milk components, casein fractions, and individual laboratory cheese yield. The $\alpha \mathrm{s} 1-\mathrm{CN}$ content was the best correlated fraction with contents of total protein, total casein, fat, and ILCY in both expressions $(\mathrm{g} / \mathrm{l}$ and \%). ILCY was significantly $(\mathrm{P}<0.002)$ correlated with contents of fat $(\mathrm{r}=0.62)$, total protein $(\mathrm{r}=0.80)$, and casein $(\mathrm{r}=0.83)$ in goat milk. These results show a strong positive correlation between ILCY and contents of fat, total protein, and particularly, casein; which, in turn, affect cheese yield during cheesemaking. Othmane et al. (2002) worked with dairy sheep and found a high correlation between ILCY and contents of total protein $(\mathrm{r}=0.91)$ and fat $(\mathrm{r}=0.76)$. Results obtained for ILCY with a small number of goat milk samples $(n=11)$ for breed have shown that this method could be sufficiently suitable to be applied in selection programs in order to optimize goat milk cheese yield.

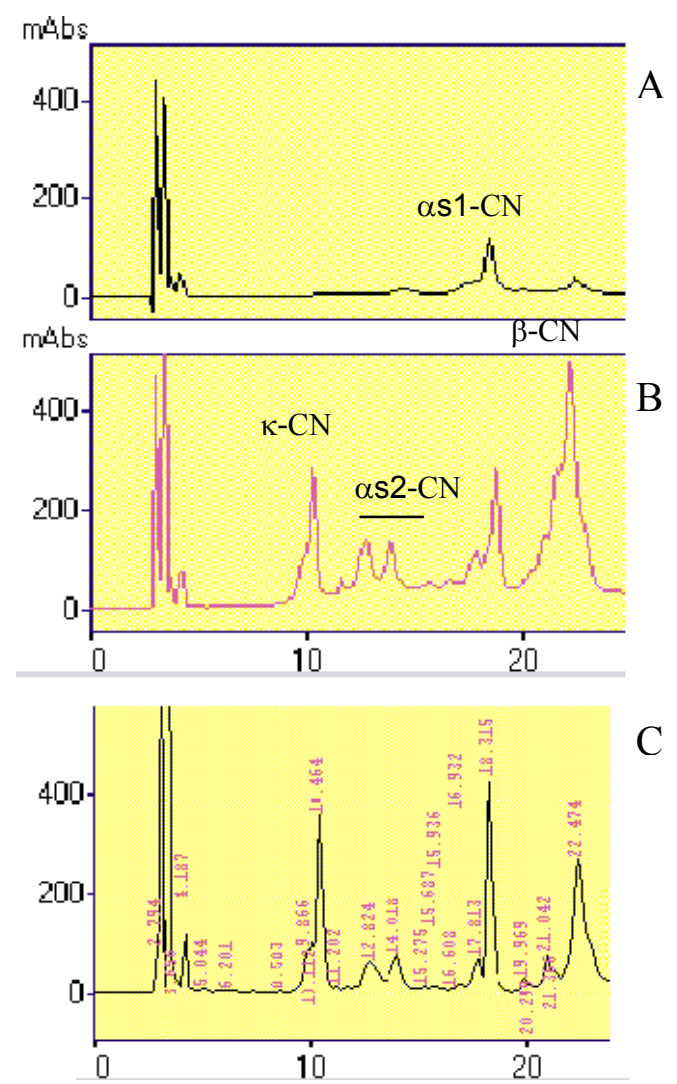

Figure 1. Chromatographic pattern of as1-CN (A) and whole casein of Saanen (B) and AngloNubian milk (C) by RP-HPLC. Chromatographic casein fractions of Anglo-Nubian milk (C) are showed with the time reports. All images are original from system of RP-HPLC.

Figure 2 shows the values of casein fractions (g/l) and ILCY in both breeds. ILCY for Anglo- 
Nubian milk was higher than for Saanen milk, as expected from the milk composition data, particularly the differences in casein content between the breeds. Cheese yield was $48 \%$ higher for Anglo-Nubian milk using the ILCY test. The higher content of as1-CN in AngloNubian milk was directly related to a higher yield of cheese when compared with Saanen milk. The $\alpha$ s1-CN fraction showed the highest differences between both breeds with nearly a three fold increase of its content in AngloNubian milk. The $\beta-\mathrm{CN}$ and $\kappa-\mathrm{CN}$ fractions were also higher in Anglo-Nubian than Saanen milk. However, no significant difference was found in the content of $\alpha \mathrm{s} 2-\mathrm{CN}$ between breeds. Expressed in relative percentages in referring to total casein (Table 1), Anglo-Nubian showed higher levels of $\alpha$ s1-CN, but less $\beta-\mathrm{CN}$ and $\alpha \mathrm{s} 2-$ $\mathrm{CN}$ than Saanen milk; moreover, no difference was found between the breeds for $\kappa-\mathrm{CN}$. The lower percentage of $\alpha$ s1-CN content and the higher percentage of $\beta-\mathrm{CN}$ in Saanen milk agree with the findings of Moatsou et al. (2004) and Tomokate et al. (2006). Also, the $\alpha$ s1-CN shows the highest variability among the casein fractions of both breeds. This paper shows the content of casein fractions expressed in two different ways for more complete information, as some papers show levels of casein fractions in g/l (MoraGutierrez et al., 1991; Clark and Sherbon, 2000) or in relative percentage (Moatsou et al., 2004) between breeds, making it difficult to compare different studies.

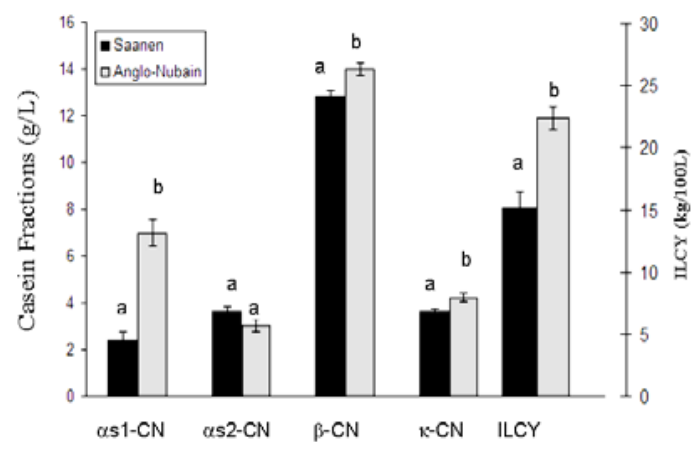

Figure 2. Casein fractions (g/l) and ILCY $(\mathrm{kg} / 1001)$ in Saanen and Anglo-Nubian goat milk $($ mean \pm SEM). Bars with different letters between breeds differ significantly $(\mathrm{P}<0.05)$.

Table 2. Pearson correlations for major milk components, casein fractions and ILCY of Saanen and Anglo-Nubian dairy goats

\begin{tabular}{|c|c|c|c|c|c|c|c|c|}
\hline & \multicolumn{2}{|c|}{$\alpha s 1-\mathrm{CN}$} & \multicolumn{2}{|c|}{$\alpha s 2-\mathrm{CN}$} & \multicolumn{2}{|c|}{$\beta-\mathrm{CN}$} & \multicolumn{2}{|c|}{$\kappa-\mathrm{CN}$} \\
\hline & $\mathrm{g} / \mathrm{L}$ & $\%$ & $\mathrm{~g} / \mathrm{L}$ & $\%$ & $\mathrm{~g} / \mathrm{L}$ & $\%$ & $\mathrm{~g} / \mathrm{L}$ & $\%$ \\
\hline Protein $(g / L)$ & $0,93 * * *$ & $0,90 * * *$ & ns & $-0,51 *$ & $0,59 * *$ & $-0,86 * * *$ & $\mathrm{~ns}$ & $-0,50 *$ \\
\hline Casein (g/L) & $0,94 * * *$ & $0,94 * * *$ & ns & $-0,55 * *$ & $0,72 * * *$ & $-0,88 * * *$ & $0,47 *$ & $-0,51^{*}$ \\
\hline Fat $(\mathrm{g} / \mathrm{L})$ & $0,62 * *$ & $0,58 * *$ & ns & ns & ns & $-0,60 * *$ & $0,48 *$ & ns \\
\hline ILCY (kg/100L) & $0,79 * * *$ & $0,78 * * *$ & ns & $-0,54 * *$ & $0,57 * *$ & $-0,75 * * *$ & $0,56 * *$ & ns \\
\hline Lactose $(\mathrm{g} / \mathrm{L})$ & ns & $\mathrm{ns}$ & $0,5^{*}$ & $0,46^{*}$ & ns & ns & ns & ns \\
\hline
\end{tabular}

$* \mathrm{P}<0,05 ; * * \mathrm{P}<0,01 ; * * * \mathrm{P}<0,001 ;$ ns: not significant $(\mathrm{P}=0,05)$.

The fraction of casein that showed the same difference between breeds in both expressions (g/1 and \%) was $\alpha \mathrm{s} 1-\mathrm{CN}$, while $\alpha \mathrm{s} 2-\mathrm{CN}, \beta-\mathrm{CN}$, and $\kappa-\mathrm{CN}$ varied depending on their expression. The concentration of $\alpha \mathrm{s} 1-\mathrm{CN}(\mathrm{g} / \mathrm{l})$ or its percentage of total casein (\%) was higher for Anglo-Nubian milk. This result was different from that reported by Clark and Sherbon (2000), who did not find differences in $\alpha$ s1-CN content between the same breeds, although AngloNubian have shown differences in as1-CN content when compared with other Swiss goat breeds (Toggenburg and Alpine). Besides the relative frequency of the alleles for $\alpha \mathrm{s} 1-\mathrm{CN}$, this casein fraction showed a strong difference between the breeds (Grosclaude et al., 1994;
Clark and Sherbon, 2000; Moatsou et al., 2004). The variants of $\alpha s 1-\mathrm{CN}$ were associated with four levels of expression defining four quantitative classes named: "high", "medium", "low", and "null" alleles related to different amounts of synthesis of $\alpha \mathrm{s} 1-\mathrm{CN}$ (Grosclaude et al., 1994). Differences found in this work in as1$\mathrm{CN}$ could be attributed to the predominance of "low" and "medium" alleles in Saanen goats, whereas Anglo-Nubian goats may have the predominance of "high" alleles for this casein fraction in the goat population.

Milk components (fat, total protein, and casein) and ILCY were positive and significantly correlated with $\alpha \mathrm{s} 1-\mathrm{CN}$ content (g/1 and \%), and 
the relationships were higher than those from the other casein fractions. These findings agree with those reported by Ambrosoli et al. (1988) and Clark and Sherbon (2000), who found that a higher content of $\alpha \mathrm{s} 1-\mathrm{CN}$ in goat milk is directly related to the contents of total solids, total protein, casein, and fat. The correlations among milk components and ILCY with $\alpha$ s $2-\mathrm{CN}, \beta-\mathrm{CN}$, and $\kappa-\mathrm{CN}$ were also variable depending on their expression (g/l or \%). Bevilacqua et al. (2001) reported that goat milk with low $\alpha \mathrm{s} 1-\mathrm{CN}$ content was less allergenic than goat milk with higher content of this fraction.

The high variability found between goat breeds and also within the same breed could be used in future selection plans targeting different uses of milk and value-added-products. Roncada et al. (2002) suggested that animals with "medium" alleles can be used to produce milk for allergic people while other genetic variants could be used to produce milk for cheesemaking dairy plants. In this study, Anglo-Nubian goats probably have "high" alleles for $\alpha$ s1-CN. Furthermore, the milk composition of this breed and the results of the ILCY study indicate advantages of this milk as a raw material for cheesemaking. On the other hand, higher milk production of Saanen goats could compensate the lower total solids production (Potter, 1996). In addition, less $\alpha$ s1$\mathrm{CN}$ content suggests advantages of this breed for fluid milk sale, which may be employed for allergic subjects (Roncada et al., 2002; Tomotake et al., 2006).

In conclusion, casein fractions analysis indicated a wide variability of $\alpha$ s1-CN with a nearly threefold increase in Anglo-Nubian milk compared to Saanen milk, which could explain the higher cheese yield and its better performance for cheesemaking. Saanen milk had a lower $\alpha$ s1-CN content, which suggests advantages of this breed for fluid milk sale.

Keywords: goats, milk, casein, cheese yield

\section{RESUMO}

Avaliaram-se os componentes, as frações de caseina e o rendimento na produção de queijo do leite de cabras das raças Saanen e Anglo-Nubiana, principais raças criadas no Uruguai. O estudo foi realizado em uma fazenda com sistema de criação semi-intensiva. O leite das cabras Anglo-Nubianas apresentou teores mais elevados de gordura (4,65 vs 3,59\%), proteína total (3,48 vs 2,84\%), caseína total (2,82 vs $2,23 \%)$, e maior rendimento na produção de queijos $(22,00$ vs $15,03 \mathrm{~kg} / 100 \mathrm{l})$ que o leite das cabras Saanen. As fraçoes de as 1-caseína (6,99 vs 2,37g/l), $\beta$-caseina $(13,95$ vs 12,75g/l) e $\kappa$-caseína $(4,24$ vs $3,64 \mathrm{~g} / \mathrm{l})$ também foram mais elevadas no leite das cabras Anglo-Nubianas, porém no teor de as2-caseina $(3,02$ vs 3,60g/l) não se observaram diferenças. O rendimento na produção de queijos foi significativamente correlacionado com os teores de gordura, proteína, caseína total e com as frações de caseína. A $\alpha_{s} 1$-caseína representou a fração com maior correlação com os teores de proteína total, caseína, gordura e produção de queijo. Demonstrou-se, neste estudo, que o leite de cabras AngloNubianas é mais indicado para a produção de queijo e o de cabras Saanen para utilização como leite fluido.

Palavras-chave: cabras, leite, caseína, queijo

\section{ACKNOWLEDGEMENTS}

This work was supported by the Comisión Sectorial de Investigación Científica (UDELAR, Uruguay). We thank José Mosquera from the farm "Los Tajamares", Canelones-Uruguay. We also thank Dr. Pedro Diaz and Mariana Sotelo for RP-HPLC assistance (Departmento de Bioquímica), Facultad de Agronomia, (UDELAR, Uruguay), and Dr. Paul Savello for critical review.

\section{REFERENCES}

AMBROSOLI, R.; Di STASIO, L.; MAZZOCO, P. Content of $\alpha_{\mathrm{s} 1}$-casein and coagulation properties in goat milk. J. Dairy Sci., v.71, p.2428, 1988.

BEVILACQUA, C.; MARTIN, P.; CANDAHL, C. et al. Goat's milk of defective $\alpha_{\mathrm{s} 1}$-casein genotype increases intestinal and systematic sensitization to $\beta$-Lactoglobulin in guinea pigs. $J$. Dairy Res., v.68, p.217-227, 2001. 
BOYAZOGLU, J.; MORAND-FEHR, P. Mediterranean dairy sheep and goat products and their quality A critical review. Small Rum. Res., v.40, p.1-11, 2001.

CLARK, S.; SHERBON, J.W. Genetic variants of alpha ${ }_{\mathrm{s} 1}-\mathrm{CN}$ in goat milk: breed distribution and associations with milk composition and coagulation properties. Small Rum. Res., v.38, p.135-143, 2000.

GROSCLAUDE， F.; RICORDEAU, G.; MARTIN, P. et al. Du gène au fromage: le polymorphisme de la caséine $\alpha_{\mathrm{s} 1}$ caprine, ses effects, son évolution. (From the gene to the cheese: goat $\alpha_{\mathrm{s} 1-}$ casein polymorphism, its effects, its evolution). INRA Prod. Anim., v.7, p.3-19, 1994.

IGARASHI, Y. Separation of caseins by chemical procedures. Int. Dairy J., v.9, p.377$378,1999$.

MOATSOU, G.; SAMOLADA, M.; PANAGIOTOU, P. et al. Casein fraction of bulk milks from different caprine breeds. Food Chem., v.87, p.75-81, 2004.

MORA-GUTIERREZ, A.; KUMOSINSKI, T.F.; FARELL, H.M. Quantification of $\alpha_{\mathrm{s} 1}$-casein in goat milk from French-Alpine and Anglo-Nubian breeds using reversed-phase high performance liquid chromatography. J. Dairy Sci., v.74, p.3303-3307, 1991.

MORONI, P.; PISONI, G.; Ruffo, G. et al. Risk factors for intramammary infections and relationship with somatic cell counts in Italian dairy goats. Prev. Vet. Med., v.69, p.163-173, 2005 .

OFFICIAL methods of analysis, 15.ed. Wasghington, DC: AOAC, 1991.

OTHMANE, H.; DE LA FUENTE, L.F.; CARRIEDO, J.A. et al. Heritability and genetic correlations of test day milk yield and composition, individual laboratory cheese yield, and somatic cell count for dairy ewes. J. Dairy Sci., v.85, p.2692-2698, 2002.

POTTER, V. Goats of the world. 1.ed. Ipswich, UK: Farming Press, 1996.

RONCADA, P.; GAVIRAGHI, A.; LIBERATORI, S. et al. Identification of caseins in goat milk. Proteomics, v.2, p.723-726, 2002.

STORRY, J.E.; GRANDISON, A.S.; MILLARD, D. et al. Chemical composition and coagulating properties of renneted milks from different breeds and species of ruminants. $J$. Dairy Res., v.50, p.215-229, 1983.

SUNG, Y.Y.; WU, T.I.; WANG, P.H. Evaluation of Milk quality of Alpine, Nubian, Saanen and Toggenburg breeds in Taiwan. Small Ruminant. Res., v.33, p.17-23, 1999. TOMOKATE, H.; OKUYAMA, R.; KATAGIRI, $M$. et al. Comparison between Holstein cow's milk and Japanese-Saanen goat's milk in fatty acid composition, lipid digestibility and protein profile. Biosci. Biotechnol. Biochem., v.70, p.2771-2774, 2006

TRUJILlO, A.J.; CASSALS, I.; GUAMIS, B. Analysis of mayor caprine milk proteins by reverse-phase high-performance liquid chromatography and electrospray ionizationmass spectrometry. J. Dairy Sci., v.83, p.11-19, 2000 .

USER'S guide: statistics. Cary, NC: SAS Institute, 2000.

WHOLE MILK: Determination of milk fat, protein and lactose contents. Guide for the operation of mid-infra-red instruments. Brussels: International Dairy Federation, 1996. (Doc. 141B). 